\title{
Monitoring Body Water Balance in Pregnant and Nursing Women: The Validity of Urine Color
}

\author{
Amy L. McKenzie Lawrence E. Armstrong \\ Department of Kinesiology, Human Performance Laboratory, University of Connecticut, Storrs, CT, USA
}

\section{Keywords}

Fluid intake $\cdot$ Hydration status · Biomarker $\cdot$ Pregnancy

Lactation $\cdot$ Urine $\cdot$ Osmolality $\cdot$ Concentration

\begin{abstract}
Background: Urine osmolality $\left(\mathrm{U}_{\mathrm{OSM}}\right)$ reflects the renal regulation of excess fluid or deficit fluid, and therefore, serves as a marker of hydration status. Little is known about monitoring hydration in pregnant and lactating women despite significant physiological challenges to body water balance during that time. Therefore, we designed a study to assess if urine color $\left(\mathrm{U}_{\mathrm{COL}}\right)$, an inexpensive and practical method, was a valid means of assessing urine concentration. Twenty-four hour $\mathrm{U}_{\mathrm{COL}}$ was significantly correlated with $24 \mathrm{~h} \mathrm{U}_{\mathrm{OSM}}$ in all women: pregnant, lactating, and control ( $r=0.61-0.84$, all $p<0.001$ ). Utilizing a receiver operating characteristic statistical analysis, we found that $24 \mathrm{~h}$ and single sample $\mathrm{U}_{\mathrm{COL}}$ had excellent diagnostic accuracy for identifying $\mathrm{U}_{\mathrm{OSM}} \geq 500 \mathrm{mOsm} \cdot \mathrm{kg}^{-1}$ in all women (area under the curve $=0.68-0.95, p<0.001-0.46$ ), and the $U_{\mathrm{COL}}$ that reflected this cut off was $\geq 4$ on the $U_{\mathrm{COL}}$ chart. Summary: Therefore, $\mathrm{U}_{\mathrm{COL}}$ is a valid marker of urine concentration and ultimately hydration status in pregnant, lactating, and non-pregnant, non-lactating women. For
\end{abstract}

\begin{tabular}{ll}
\hline KARGER & $\begin{array}{l}\text { (c) } 2017 \text { The Author(s) } \\
\text { Published by S. Karger AG, Basel }\end{array}$ \\
$\begin{array}{l}\text { E-Mail karger@karger.com } \\
\text { www.karger.com/anm }\end{array}$ & $\begin{array}{l}\text { This article is licensed under the Creative Commons Attribution- } \\
\text { NonCommercial-NoDerivatives 4.0 International License (CC BY- } \\
\text { NC-ND) (http://www.karger.com/Services/OpenAccessLicense). } \\
\text { Usage and distribution for commercial purposes as well as any dis- } \\
\text { tribution of modified material requires written permission }\end{array}$
\end{tabular}

pregnant, lactating, and control women, the $\mathrm{U}_{\mathrm{COL}}$ chart is a valid tool that can be used to monitor urine concentration in a single sample or over the course of the day via a $24 \mathrm{~h}$ sample. Key Message: Women who present with a $\mathrm{U}_{\mathrm{COL}}$ of 4 or more likely have $\mathrm{U}_{\mathrm{OSM}} \geq 500 \mathrm{mOsm} \cdot \mathrm{kg}^{-1}$. Given the positive health benefits associated with $U_{O S M}<500 \mathrm{mOsm} \cdot \mathrm{kg}^{-1}$, women should aim for a 1,2 , or 3 on the $U_{\mathrm{COL}}$ chart. If a $U_{\mathrm{COL}}$ of $\geq 4$ is observed, women should consider increasing fluid consumption to improve hydration status.

(C) 2017 The Author(s)

Published by S. Karger AG, Basel

\section{The Importance of Monitoring Body Water Balance during Pregnancy and Nursing}

Water is essential for life and it plays a key role in maintaining the metabolic activities of the body through its contribution to cell volume homeostasis. Changes in cell volume have important implications for trafficking of nutrients and waste, while also affecting cellular metabolism and gene expression [1]. The largest source of water intake each day is obtained from the fluids we drink [2], and consuming inadequate fluid volumes for the body's

Amy L. McKenzie, PhD

Department of Kinesiology

Human Performance Laboratory, University of Connecticut

2095 Hillside Drive U1110, Storrs, CT 06269-1110 (USA)

E-Mail amylmckenzie@gmail.com 
needs results in lower water turnover through the kidneys and higher urine concentrations [3]. These characteristics of low fluid intake, low urine volume, and high urine concentration have been associated with negative health consequences, including chronic kidney disease [4], increased rate of decline in kidney function [5], constipation [6], and poor glucose homeostasis [7, 8]. Further, increased water intake for maintaining low urine concentration has been recommended for the treatment or prevention of constipation $[9,10]$, urolithiasis [11], and nephrolithiasis [12].

While adequacy of water intake seems important for the health of the general person, it is especially important during pregnancy and lactation, considering the challenges to fluid homeostasis and the watery environment in which the fetus develops. As early as the sixth week of gestation, the total blood volume expands and cardiac output increases [13]. Concurrently, the renal system increases the glomerular filtration rate, while maintaining a balance of natriuretic and anti-natriuretic factors to retain sodium and water levels throughout pregnancy [14]. This water retention is necessary for the development and maintenance of amniotic fluid and other components of gestation [13]. Following gestation, the need for additional fluid continuing as fluid balance is challenged during nursing. Nursing mothers lose an additional $\sim 700 \mathrm{~mL}$ water per day via breast milk at 8 weeks postpartum [15]. Breast milk volume is defended across a wide range of fluid intakes; however, at lower total fluid intakes, nursing women consuming the same amount of fluid as nonlactating women, with slightly higher urine concentrations, demonstrate the additional challenge to fluid balance and importance of adequate fluid intake for nursing mothers [16].

\section{Monitoring Hydration Status}

Reference total water intakes range from about 2-2.8 L per day for women who are not pregnant or nursing; these values increase by $300 \mathrm{~mL}$ per day during pregnancy [2, 17-19]. However, these reference values are often based on population average or median intakes. In contrast, formulating a personalized assessment of hydration status for each woman, based on her unique fluid challenges and water needs, is therefore sensible. Women gain water from food, metabolism, and by consuming fluids; they experience water losses mostly through urine excretion, but also lose water

Validity of $\mathrm{U}_{\mathrm{COL}}$ in Pregnant, Nursing Women through skin, respiration, feces, and sweat [20]. However, in the case of nursing women, an additional 400$800 \mathrm{~mL}$ of water is lost each day through breast milk [15].

Urine osmolality ( $\mathrm{U}_{\mathrm{OSM}}$ ) has been described as a marker that reflects the renal regulation of fluid excess or deficit [21], and therefore, is a marker of hydration status and water turnover. The $24 \mathrm{~h} \mathrm{U}_{\mathrm{OSM}}$ can also serve as an index for adequate water intake from a physiological and health perspective [22]. Twenty-four hour $\mathrm{U}_{\mathrm{OSM}}$ lower than approximately $500 \mathrm{mOsm} \cdot \mathrm{kg}^{-1}$ have been associated with positive health outcomes such as lower incidence of kidney stones and prevention of recurrent stones [22]. Physiologically, higher $\mathrm{U}_{\mathrm{OSM}}$ and lower fluid intakes are associated with a higher plasma concentration of the fluid-regulating hormone vasopressin, as well as its more stable surrogate marker, copeptin. In pregnant women, high plasma copeptin concentration has been associated with pre-eclampsia [23]. Additionally, increased fluid consumption is indicated in the presence of oligohydramnios for the purpose of increasing amniotic fluid volume [24], as well as for the alleviation of constipation during pregnancy $[9,10]$. Thus, maintaining an adequate fluid intake with a lower urine concentration appears to be the right thing to do during pregnancy and while nursing.

\section{Using Urine Color to Monitor the Hydration Status of Pregnant and Nursing Women}

Previous research has tracked urinary markers of body water balance during pregnancy and the postpartum period but without consideration of total fluid intake, experimental controls, or comparison to non-pregnant and non-nursing women [25]. Therefore, we designed a study to assess whether urine color $\left(\mathrm{U}_{\mathrm{COL}}\right)$, an inexpensive and practical tool, was a valid means of assessing urine concentration, and thus a valid means of monitoring body water balance [26].

The University of Connecticut Institutional Review Board approved this study, and all participants provided voluntary informed consent to participate. Eighteen pregnant women (age: $31 \pm 3$ years, height: $165.5 \pm 6.7 \mathrm{~cm}$, body mass: $66.89 \pm 19.24 \mathrm{~kg}$ ) were pair-matched to 18 control women (age: $29 \pm 4$ years, height: $163.7 \pm 8.29 \mathrm{~cm}$, body mass: $64.83 \pm 13.84 \mathrm{~kg}$ ) and were enrolled in the study. These characteristics were similar between groups at the end of the first trimester and again at $3 \pm 1$ weeks 

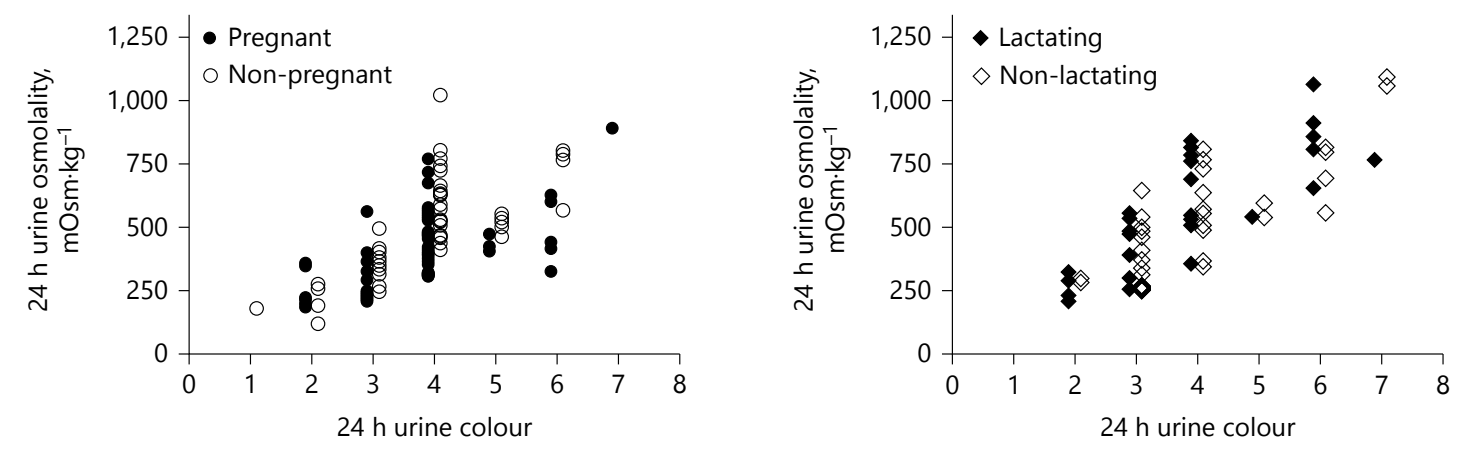

Fig. 1. Relationships of $24 \mathrm{~h} \mathrm{U}_{\mathrm{COL}}$ to $24 \mathrm{~h} \mathrm{U}_{\mathrm{OSM}}$ during pregnancy and lactation. Individual data points represent $24 \mathrm{~h} \mathrm{U} \mathrm{COL}_{\mathrm{L}}$ and $24 \mathrm{~h}$ $\mathrm{U}_{\text {OSM }}$ for pregnant (visits $1-3$ pooled, $r=0.6085, p<0.0001$ ), nonpregnant (visits $1-3$ pooled, $r=0.7826, p<0.0001$ ), lactating (vis- its 4-5 pooled, $r=0.8390, p<0.0001)$, and non-lactating women (visits 4-5 pooled, $r=0.7736, p<0.0001$ ). Reprinted from McKenzie et al. [26]. postpartum during lactation, compared to women who were not lactating (all $p>0.05$ ).

Data were collected from pregnant women at the end of the first, second, and third trimesters and at $3 \pm 1$ and $9 \pm 1$ weeks postpartum. Control women were taking a combination drug oral contraceptive; data was collected only during the early follicular phase of the menstrual cycle and observed at similar time intervals to the pregnant/lactating participants. On the day of each observation, women collected a $24 \mathrm{~h}$ urine sample, plus all individual single samples from any overnight voids following a $200 \mathrm{~mL}$ water bolus before going to sleep. Osmolality (via freezing point depression osmometry), specific gravity ( $\mathrm{U}_{\mathrm{SG}}$; via refractometer), and color (via a previously published $U_{\mathrm{COL}}$ scale [27] ranging from 1 to 8 , lightest to darkest) were assessed in each of these samples.

Using these biomarkers, we assessed the validity of $\mathrm{U}_{\mathrm{COL}}$ in 2 ways. The first aim was to evaluate the relationship between $24 \mathrm{~h} \mathrm{U} \mathrm{COL}_{\mathrm{L}}$ and other markers of hydration, $24 \mathrm{~h} \mathrm{U}_{\mathrm{OSM}}$ and $24 \mathrm{~h} \mathrm{U}_{\mathrm{SG}}$. Twenty-four hour $\mathrm{U}_{\mathrm{COL}}$ was significantly correlated with $24 \mathrm{~h} \mathrm{U}_{\mathrm{OSM}}$, the gold standard for evaluating urine concentration, in all women: pregnant, lactating, and control (Fig. $1 ; r=0.61-0.84$, all $p<$ $0.001)$. Twenty-four hour $\mathrm{U}_{\mathrm{COL}}$ was also significantly correlated with $24 \mathrm{~h} \mathrm{U}_{\mathrm{SG}}$ in all women $(r=0.62-0.89$, all $p<$ 0.001).

The second aim was to determine whether $\mathrm{U}_{\mathrm{COL}}$ in $24 \mathrm{~h}$ and single samples could accurately determine whether $\mathrm{U}_{\mathrm{OSM}}$ was greater than or equal to the $500 \mathrm{mOsm} \cdot \mathrm{kg}^{-1}$ threshold associated with less desirable health outcomes. Utilizing a receiver operating characteristic statistical analysis, we found that $24 \mathrm{~h} \mathrm{U}_{\mathrm{COL}}$ had excellent diagnostic accuracy for identifying $\mathrm{U}_{\mathrm{OSM}} \geq 500 \mathrm{mOsm} \cdot \mathrm{kg}^{-1}$ in all women (area under the curve $=0.68-0.95, p<0.001-0.46$ ) and the $\mathrm{U}_{\mathrm{COL}}$ that reflected this cut off was $\geq 4$ on the $\mathrm{U}_{\mathrm{COL}}$ chart. When choosing the best criterion value for the test, a tradeoff between sensitivity and specificity between the 4 and 5, respectively, was present (Table 1). A criterion value of 4 provided a more sensitive cut off, identifying as many of the samples with $\mathrm{U}_{\mathrm{OSM}} \geq 500 \mathrm{mOsm} \cdot \mathrm{kg}^{-1}$ as possible. A criterion value of 5 was more specific, resulting in very few false positives (i.e., a $\mathrm{U}_{\mathrm{COL}}$ of 5 or higher that is actually $<500 \mathrm{mOsm} \cdot \mathrm{kg}^{-1}$ ).

While $24 \mathrm{~h}$ urine collection is the gold standard for assessing the $24 \mathrm{~h}$ fluid balance, collecting $24 \mathrm{~h}$ samples repeatedly in order to monitor body water balance can be impractical. Further, a woman may want to try out a change in fluid consumption throughout the day based on the color of each individual sample. Here, we evaluated the diagnostic accuracy of individual samples and found that single samples also accurately identified $\mathrm{U}_{\mathrm{OSM}}$ $\geq 500 \mathrm{mOsm} \cdot \mathrm{kg}^{-1}$ with excellent accuracy and sensitivity (Table 1). Figure 2 depicts the relationship between single-sample $\mathrm{U}_{\mathrm{OSM}}$ and single-sample $\mathrm{U}_{\mathrm{COL}}$. Given the high sensitivity of the test, we can confidently rule out $\mathrm{U}_{\mathrm{OSM}}$ $\geq 500 \mathrm{mOsm} \cdot \mathrm{kg}^{-1}$ when $\mathrm{U}_{\mathrm{COL}}$ of 1,2 , or 3 is observed. Given the importance of water balance during pregnancy, it appears prudent to choose the criterion value with higher sensitivity than specificity. 
Table 1. Results of the receiver operating characteristic statistical analyses

\begin{tabular}{|c|c|c|c|c|c|c|}
\hline Group & AUC & SE & $p$ value & Criterion value & Sensitivity & Specificity \\
\hline \multicolumn{7}{|c|}{ Diagnostic accuracy of $U_{C O L}$ to identify $U_{O S M} \geq 500 \mathrm{mOsm} \cdot \mathrm{kg}^{-1}$ in $24 \mathrm{~h}$ samples } \\
\hline Pregnant & 0.685 & 0.077 & 0.046 & $\begin{array}{l}4 \\
5\end{array}$ & $\begin{array}{l}0.92 \\
0.23\end{array}$ & $\begin{array}{l}0.41 \\
0.85\end{array}$ \\
\hline Lactating & 0.951 & 0.036 & $<0.0001$ & $\begin{array}{l}4 \\
5\end{array}$ & $\begin{array}{l}0.91 \\
0.36\end{array}$ & $\begin{array}{l}0.93 \\
1.0\end{array}$ \\
\hline Control & 0.911 & 0.031 & $<0.0001$ & $\begin{array}{l}4 \\
5\end{array}$ & $\begin{array}{l}0.96 \\
0.38\end{array}$ & $\begin{array}{l}0.80 \\
0.98\end{array}$ \\
\hline \multicolumn{7}{|c|}{ Diagnostic accuracy of $U_{C O L}$ to identify $U_{O S M} \geq 500 \mathrm{mOsm} \cdot \mathrm{kg}^{-1}$ in single samples } \\
\hline Pregnant & 0.919 & 0.019 & $<0.0001$ & $\begin{array}{l}4 \\
5\end{array}$ & $\begin{array}{l}0.98 \\
0.65\end{array}$ & $\begin{array}{l}0.70 \\
0.93\end{array}$ \\
\hline Lactating & 0.922 & 0.024 & $<0.0001$ & $\begin{array}{l}4 \\
5\end{array}$ & $\begin{array}{l}0.90 \\
0.52\end{array}$ & $\begin{array}{l}0.78 \\
1.0\end{array}$ \\
\hline Control & 0.909 & 0.021 & $<0.0001$ & $\begin{array}{l}4 \\
5\end{array}$ & $\begin{array}{l}0.86 \\
0.50\end{array}$ & $\begin{array}{l}0.88 \\
0.96\end{array}$ \\
\hline
\end{tabular}

Modified from McKenzie et al. [26].

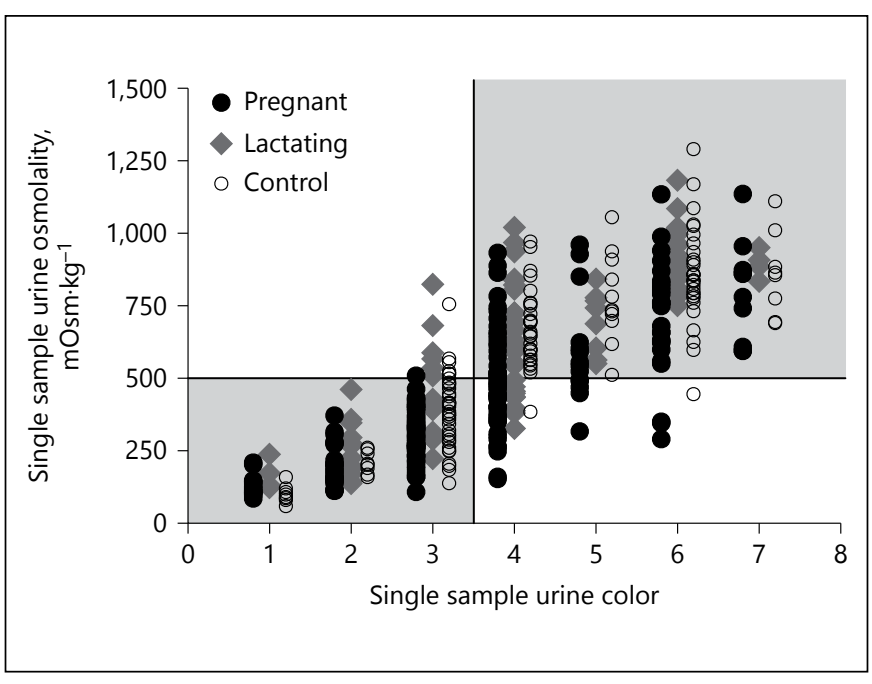

Fig. 2. Contingency plots for $U_{\mathrm{COL}}$ and $U_{\mathrm{OSM}}$ in single samples. Vertical line represents the $\mathrm{U}_{\mathrm{COL}} \geq 4$ criterion value determined by the receiver operating characteristic curve analysis to identify $\mathrm{U}_{\mathrm{OSM}} \geq 500 \mathrm{mOsm} \cdot \mathrm{kg}^{-1}$ (horizontal line). Modified from McKenzie et al. [26].

Considering all of the aforementioned analyses, we conclude that $\mathrm{U}_{\mathrm{COL}}$ is a valid marker of urine concentration and ultimately of body water balance in pregnant, lactating, and non-pregnant, non-lactating women because it was significantly correlated with other markers of hydration status such as $\mathrm{U}_{\mathrm{OSM}}$ and $\mathrm{U}_{\mathrm{SG}}$. For pregnant, lactating, and control women, the $\mathrm{U}_{\mathrm{COL}}$ chart is a valid tool that can be used to monitor urine concentration in a single sample, or across the entire day through a $24 \mathrm{~h}$ sample.

Women who present with a $\mathrm{U}_{\mathrm{COL}}$ of 4 or more likely have a $U_{O S M} \geq 500 \mathrm{mOsm} \cdot \mathrm{kg}^{-1}$. Given the positive health benefits associated with $\mathrm{U}_{\mathrm{OSM}}$ under that threshold (see above), women should aim for a 1,2 , or 3 on the $\mathrm{U}_{\mathrm{COL}}$ chart. If a $\mathrm{U}_{\mathrm{COL}}$ of $\geq 4$ is observed, women should consider increasing fluid consumption to improve hydration status.

\section{Acknowledgment}

The authors would like to thank Erica Perrier, $\mathrm{PhD}$, Alexis Klein, $\mathrm{PhD}$, Isabelle Guelinckx, $\mathrm{PhD}$, Stavros Kavouras, $\mathrm{PhD}$, Colleen Muñoz, PhD, and Lindsay Ellis, MS for their assistance in this project. The authors are also very grateful to the subjects in this study for their dedicated participation.

\section{Disclosure Statement}

Danone research funded the research presented in McKenzie et al. $[16,26]$ and in these proceedings. A.L.M. and L.E.A. received from Danone Research reimbursement of travel expenses and registration fee to attend the $\mathrm{H} 4 \mathrm{H}$ Scientific Conference. The full disclosure statement for L.E.A. appears above on the page preceeding the Table of Contents. 


\section{References}

1 Häussinger D, Lang F: Cell volume in the regulation of hepatic function: a mechanism for metabolic control. Biochim Biophys Acta 1991;1071:331-350.

2 Institute of Medicine (US): Panel on Dietary Reference Intakes for Electrolytes, Water. DRI, Dietary Reference Intakes for water, potassium, sodium, chloride, and sulfate. Institute of Medicine of the National Academies, 2005.

3 Perrier E, Rondeau P, Poupin M, Le Bellego L, Armstrong LE, et al: Relation between urinary hydration biomarkers and total fluid intake in healthy adults. Eur J Clin Nutr 2013;67:939943.

4 Strippoli GF, Craig JC, Rochtchina E, Flood VM, Wang JJ, Mitchell P: Fluid and nutrient intake and risk of chronic kidney disease. $\mathrm{Ne}$ phrology (Carlton) 2011;16:326-334.

5 Clark WF, Sontrop JM, Macnab JJ, Suri RS, Moist L, Salvadori M, et al: Urine volume and change in estimated GFR in a communitybased cohort study. Clin J Am Soc Nephrol 2011;6:2634-2641.

6 Derbyshire E, Davies J, Costarelli V, Dettmar $P$ : Diet, physical inactivity and the prevalence of constipation throughout and after pregnancy. Matern Child Nutr 2006;2:127-134.

7 Roussel R, Fezeu L, Bouby N, Balkau B, Lantieri O, Alhenc-Gelas F, et al: Low water intake and risk for new-onset hyperglycemia. Diabetes Care 2011;34:2551-2554.

8 Melander O: Vasopressin, from regulator to disease predictor for diabetes and cardiometabolic risk. Ann Nutr Metab 2016;68(suppl 2): $24-28$.
9 Derbyshire E: The importance of adequate fluid and fibre intake during pregnancy. Nurs Stand 2007;21:40-43.

10 Cullen G, O'Donoghue D: Constipation and pregnancy. Best Pract Res Clin Gastroenterol 2007;21:807-818.

11 Türk C, Knoll T, Petrik A, Sarica K, Straub M, Seitz C: Guidelines on Urolithiasis, 2012.

12 Finkielstein VA, Goldfarb DS: Strategies for preventing calcium oxalate stones. CMAJ 2006;174:1407-1409.

13 Hytten FE, Thomson AM, Taggart N: Total body water in normal pregnancy. J Obstet Gynaecol Br Commonw 1966;73:553-561.

14 Lumbers ER, Pringle KG: Roles of the circulating renin-angiotensin-aldosterone system in human pregnancy. Am J Physiol Regul Integr Comp Physiol 2014;306:R91-R101.

15 Neville MC, Keller R, Seacat J, Lutes V, Neifert $M$, Casey C, et al: Studies in human lactation: milk volumes in lactating women during the onset of lactation and full lactation. Am J Clin Nutr 1988;48:1375-1386.

16 McKenzie AL, Perrier ET, Guelinckx I, Kavouras SA, Aerni G, Lee EC, et al: Relationships between hydration biomarkers and total fluid intake in pregnant and lactating women. Eur J Nutr 2016, Epub ahead of print.

17 European Food Safety Authority, Agostoni CV, Bresson JL, Fairweather-Tait S, Flynn A: Scientific opinion on dietary reference values for water. EFSA J 2010;8:1459.

18 NHMRC: Nutrient Reference Values for Australia and New Zealand Including Recommended Dietary Intakes, 2006, pp 1-317.

19 World Health Organization: Nutrients in Drinking Water. Geneva, World Health Organization, 2005.

20 Perrier ET, Armstrong LE, Daudon M, Kavouras S, Lafontan M, Lang F, et al: From state to process: defining hydration. Obes Facts 2014;7(suppl 2):6-12.
21 Manz F, Wentz A: 24-h hydration status: parameters, epidemiology and recommendations. Eur J Clin Nutr 2003;57(suppl 2):S10S18.

22 Perrier ET, Buendia-Jimenez I, Vecchio M, Armstrong LE, Tack I, Klein A: Twenty-fourhour urine osmolality as a physiological index of adequate water intake. Dis Markers 2015; 2015:231063.

23 Santillan MK, Santillan DA, Scroggins SM, Min JY, Sandgren JA, Pearson NA, et al: Vasopressin in preeclampsia: a novel very early human pregnancy biomarker and clinically relevant mouse model. Hypertension 2014; 64:852-859.

24 Hofmeyr GJ, Gülmezoglu AM, Novikova N: Maternal hydration for increasing amniotic fluid volume in oligohydramnios and normal amniotic fluid volume. Cochrane Database Syst Rev 2002;1:CD000134.

25 van Buul EJ, Steegers EA, Jongsma HW, Eskes TK, Thomas CM, Hein PR: Haematological and biochemical profile of uncomplicated pregnancy in nulliparous women; a longitudinal study. Neth J Med 1995;46:7385.

26 McKenzie AL, Muñoz CX, Ellis LA, Perrier ET, Guelinckx I, Klein A, et al: Urine color as an indicator of urine concentration in pregnant and lactating women. Eur J Nutr 2017; 56:355-362.

27 Armstrong LE, Maresh CM, Castellani JW, Bergeron MF, Kenefick RW, LaGasse KE, et al: Urinary indices of hydration status. Int J Sport Nutr 1994;4:265-279. 